\title{
KEGAWATDARURAT AN PSIKOLOGIS BERUPA TINGKAT STRES, KECEMASAN DAN DEPRESI KORBAN GEMPA, TSUNAMI DAN LIKUIFAKSI DI WILAYAH PANTOLOAN KABUPATEN DONGGALA PALU SULAWESI TENGAH
}

\author{
Miranti Florencia Iswari \\ Program Studi IImu Keperawatan STIKes Muhammadiyah Palembang \\ Email: umydirajuna@gmail.com
}

\begin{abstract}
ABSTRAK
Pendahuluan: Korban bencana tidak hanya mengalami masalah darurat seperti pembangunan, makanan, kondisi fisik akibat gempa namun juga masalah kesehatan mental. Setelah peristiwa bencana, sebagian besar populasi korban bencana tetap memiliki reaksi psikologis yang normal, akan tetapi $15-20 \%$ akan mengalami gangguan mental ringan atau sedang yang merujuk pada kondisi PTSD (Post Traumatic Stress Disorder), sementara 3$4 \%$ akan mengalami gangguan berat seperti psikosis, depresi berat dan kecemasan yang tinggi. Tujuan penelitian: untuk menjelaskan tentang kegawatdaruratan psikologis berupa tingkat stress, kecemasan dan depresi yang terjadi pada korban bencana gempa, tsunami dan likuifaksi wilayah pantoloan Kabupaten Donggala Palu Sulawesi Tengah. Populasi dalam penelitian ini adalah para pengungsi di tenda-tenda pengungsian di wilayah Pantoloan Kabupaten Donggala dan sampel berjumlah 33 responden ditentukan dengan teknik total sampling. Metode: yang digunakan yaitu kuantitatif dengan rancangan penelitian deskriptif. Pengumpulan data menggunakan Instrumen penelitian questioner DASS 42 dengan teknik wawancara dan observasi. Hasil penelitian: didapatkan tingkat stress terbanyak pada kategori berat yaitu 17 orang (51.5\%), tingkat kecemasan terbanyak kategori berat yaitu 30 orang $(90.9 \%)$, dan tingkat depresi terbanyak kategori ringan yaitu 22 orang $66.7 \%$ ).
\end{abstract}

Kata Kunci: Kegawatdaruratan psikologis, Kecemasan, Stres, Depresi

\section{ABSTRACT}

Introduction: Disaster victims not only experience emergency problems such as construction, food, physical condition due to the earthquake but also mental health problems. After a catastrophic event, the majority of the disaster victims population still has a normal psychological reaction, but $15-20 \%$ will experience mild or moderate mental disorders that refer to the condition of PTSD (Post Traumatic Stress Disorder), while 3-4\% will experience severe disorders like psychosis, major depression and high anxiety. The purpose of the study: to explain the psychological emergencies in the form of stress, anxiety and depression that occur in victims of the earthquake, tsunami and liquefaction of the Pantoloan area, Donggala Palu, Central Sulawesi. The population in this study were refugees in refugee tents in the Pantoloan area of Donggala Regency and a sample of 33 respondents was determined by total sampling technique. Method: used is quantitative with descriptive research design. Data collection using the DASS 42 questioner research instrument with interview and observation techniques. Results: the highest levels of stress were found in the severe category of 17 people (51.5\%), the most severe level of anxiety was 30 people (90.9\%), and the mildest level of depression was 22 people 66.7\%).

Keyword: Psychological emergency, Anxiety, Stress, Depresion 


\section{PENDAHULUAN}

Bencana merupakan peristiwa atau rangkaian peristiwa yang mengancam dan mengganggu kehidupan dan penghidupan masyarakat yang disebabkan oleh faktor alam dan/atau faktor non-alam maupun faktor manusia sehingga mengakibatkan timbulnya korban jiwa manusia, kerusakan lingkungan, kerugian harta benda dan bencana sosial ${ }^{1}$. Indonesia adalah salah satu negara yang memiliki prevalensi yang tinggi untuk terjadinya bencana dan berada pada peringkat ke- 6 dari negaranegara yang sering dilanda bencana alam, terutama untuk jenis geofisikal dan meteorologi².

Pulau Sulawesi secara geologis diyakini oleh para ahli kebumi anter letak pada pertemuan empat lempeng (complex junction) utama dunia yaitu lempeng Eurasia, lempeng Indo-Australia, lempeng pasifik, dan satu lempeng filipina. Dampak dari kondisi ini mengakibatkan pulau Sulawesi menjadi wilayah yang sangat rawan bencana alam ke bumian khususnya bencana gempa bumi. Berdasarkan distribusi seismisitas, tampak Cluster aktivitas gempa bumi yang cukup tinggi di sepanjang sesar aktif Palu-Koro hingga memotong kota Palu ${ }^{3}$.

Bencana alam gempa bumi meningkatkan perhatian akan masalah kesehatan yang ditimbulkansecara global ${ }^{4}$.Korban gempa tidak hanya mengalami masalah darurat seperti pembangunan, makanan kondisi fisik akibat gempa namun juga masalah kesehatan mental ${ }^{5}$. Sebuah survey menunjukkan bahwa setelah peristiwa bencana, sebagian besar populasi korban bencana tetap memiliki reaksi psikologis yang normal, akan tetapi $15-20 \%$ akan mengalami gangguan mental ringan atau sedang yang merujuk pada kondisi PTSD (Post Traumatic Stress Disorder), sementara $3-4 \%$ akan mengalami gangguan berat seperti psikosis, depresi berat dan kecemasan yang tinggi ${ }^{6}$.

Distress yang berkaitan dengan bencana alam akan berlangsung lama setelah insiden ${ }^{7,8}$. Kondisi tersebut akan semakin memburuk bila tidak dideteksi sejak dini dan ditangani dengan baik, sehingga membutuhkan pelayanan kesehatan mental (mental healing), baik itu untuk menanggulangi stress, cemas dan depresi ${ }^{5}$.

\section{METODE PENELITIAN}

Jenis penelitian ini adalah metode kuantitatif dengan rancangan penelitiandeskriptifanalitik. Populasi dalam penelitian ini adalah para pengungsi yang terpaksa mengungsi di tenda-tenda pengungsian di wilayah Pantoloan Kabupaten Donggala karena kehilangan tempat tinggal dan harta benda akibat gempa, tsunami dan likuifaksi Palu Sulawesi Tengah. Sampel berjumlah 33 orang dengan teknik total sampling Instrumen penelitian inimenggunakan questioner DASS 42 dengan teknik wawancara dan observasi. Pengamatan dilakukan dengan melihat langsung reaksi responden ketika dilakukan wawancara. Reaksi yang muncul antara lain mata berbinar dan menangis, melamun.

\section{HASIL PENELITIAN}

Berdasarkan table karakteristik responden didapatkan jenis kelamin terbanyak yaitu laki-laki sebanyak 20 orang $(60.6 \%)$ dan tingkat pendidikan terbanyak yaitu SMA sebanyak 18 orang (54.5\%) (Tabel 1).

Hasil distribusi frekuensi tingkat kecemasan, stress dan depresi para pengungsi bencana gempa, tsunami dan likufaksi di wilayah Pantoloan Palu Sulawesi tengah menunjukkan tingkat stress terbanyak pada kategori berat yaitu 17 orang (51.5\%), tingkat kecemasan terbanyak pada kategori berat yaitu 30 
orang (90.9\%), dan tingkat depresi responden (66,7\%) (Tabel 2). terbanyak pada kategori ringan yaitu 22

Tabel.1 Karakteristik Responden

\begin{tabular}{clcc}
\hline \multirow{3}{*}{ Jenis Kelamin } & Frekuensi & Persentase (\%) \\
\cline { 2 - 4 } & Kategori & 20 & 60.6 \\
& Laki-laki & 13 & 39.4 \\
& Perempuan & 3 & 9.1 \\
& SD & 10 & 30.3 \\
& SMP & 18 & 54.5 \\
& SMA & 2 & 6.1 \\
\hline & PT & $\mathbf{3 3}$ & $\mathbf{1 0 0}$ \\
\cline { 2 - 4 }
\end{tabular}

Tabel.2 TingkatKecemasan, Stres dan Depresi Responden

\begin{tabular}{clcc}
\hline \multirow{3}{*}{ Stress } & Kategori & Frekuensi & Persentase (\%) \\
\cline { 2 - 4 } Cemas & Ringan & 6 & 18.2 \\
& Sedang & 10 & 30.3 \\
& Berat & 16 & 51.5 \\
& Ringan & - & - \\
& Sedang & 3 & 9,1 \\
& Berat & 30 & 90,9 \\
Depresi & Ringan & 22 & 66.7 \\
& Sedang & 11 & 33.3 \\
\cline { 2 - 4 } & Berat & & $\mathbf{1 0 0}$ \\
\cline { 2 - 4 } & TOTAL & $\mathbf{3 3}$ & \\
\hline
\end{tabular}

\section{PEMBAHASAN}

\section{Tingkat Stres}

Berdasarkan hasil analisis univariat dari 33 responden menunjukkan bahwa stres pada korban bencana gempa, tsunami dan likuifaksi ditingkat stres ringan berjumlah 6 responden $(18,2$ $\%)$, tingkat stres sedang berjumlah 10 responden $(30,3 \%)$, dan tingkat stres berat berjumlah 17 responden (51,5\%). Sehingga mayoritas stres pada korban bencana berada pada tingkat stres berat (51,5\%).

Stres merupakan masalah umum yang terjadi dalam kehidupan manusia. Stres adalah kondisi yang tidakmenyenangkandimanamanusiamelih atadanya tuntutan dalam suatu situasi sebagai beban atau diluar batas kemampuan individu untuk memenuhi tuntutan tersebut ${ }^{9}$. Suatu pengalaman emosional yang bersifat negatif dan dapat diprediksi secara biokimia, fisiologis, kognitif, dan perubahan perilaku terhadap stress full event. Stressfull event bagi setiap individu berbeda-beda. Stressfull event dapat memberikan pengaruh negatif pada individu yang mengalami, sehingga individu tersebut dapat menjadi marah, tegang, bingung, dan cemas. Stres ini dapat menghilang dengan cepat atau membutuhkan waktu berminggu-minggu atau bahkan berbulan-bulan. Stres ini dapat menurunkan sistem kekebalan tubuh $^{10}$.

Menurut ${ }^{11,}$ seseorang yang mengalami peristiwa bencana secara langsung cenderung menghindari kontak langsung atau situasi yang dapat 
mengingatkan kembali pada peristiwa tersebut. Bencana alam, termasuk gempa bumi dan tsunami pada hakikatnya merupakan sumber stres. Setiap keadaan atau peristiwa yang menyebabkan perubahan dalam kehidupan seseorang, sehingga individu terpaksa mengadakan adaptasi stressor yang timbul. Dalam perspektif psikologi, stres bisa dipahami sebagai sebuah keadaan tertekan pada sebuah sistem atau individu, baik secara fisik maupun individual. Karakteristik korban yang mengalami stres bencana ditandai dengan gejala-gejala rasa takut yang intens, ketidakberdayaan, atauhoror yang menakutkan karena peristiwa yang traumatis. Kejadian dapat juga terjadi pada korban yang masih selamat dari bencana kemudian mengalami ancaman kematian akibat luka-luka dan infeksi, kerugian harta benda serta melihat langsung kematian ${ }^{12}$.

Hasil penelitian ini sesuai dengan penelitian yang dilakukan oleh ${ }^{13}$, yang menyatakan bahwa stres pada korban bencana sebagian besar responden mengalami gejala stres berat sebanyak 30 responden $\quad(78,9 \%)$ sedangkan responden yang tidak mengalami gejala stres sebanyak 8 responden $(21,1 \%)$.

Berdasarkan hasil penelitian dan teori terkait, maka peneliti berpendapat bahwa tingkat stres pada responden ditingkat berat dikarenakan individu yang tidak bisa menerima kenyataan secara umum akan mengalami tingkat stres yang lebih tinggi sehingga membuat responden mengalami penderitaan yang menyengsarakan. Seseorang yang mengalami stres akan melibatkan emosinya,

ketikarespondenmengalamistres yang berlangsung terus-menerus, maka selanjutnya stres responden berada pada tahap terakhir.

\section{Tingkat Kecemasan}

Berdasarkan hasil penelitian dari 33 responden menunjukan bahwa korban bencana gempa, tsunami dan likuifaksi didapatkan tidak ada korban yang mengalami tingkat kecemasan ringan, terdapat 3 responden (9.1\%) responden dengan tingkat kecemasan sedang, dan 30 responden (90.9\%) responden dengan tingkat kecemasan berat.

Kecemasan merupakan respon individu terhadap suatu keadaan yang tidak menyenangkan dan dialami oleh semua makhluk hidup dalam kehidupan sehari-hari. Kecemasan merupakan pengalaman subjektif dari individu dan tidak dapat diobservasi secara langsung serta merupakan suatu keadaan emosi tanpa subjek yang spesifik. Kecemasan terjadi sebagai akibat dari ancaman terhadap diri sendiri atau identitas diri yang sangat mendasar bagi keberadaan individu ${ }^{14}$.

Kecemasan (ansietas) adalah suatu respon normal individu terhadap pertumbuhan, perubahan, pengalaman baru, penemuan identitas dan makna hidup. Ansietas muncul dengan gejala pusing, rasa melayang, hiperhidrosis, diare, hiperrefleksi, hipertensi, palpitasi, pupil midriasis, gelisah, sinkop (pingsan), takikardia (denyut jantung cepat), rasa gatal, tremor dan gangguanlambung. Ansietas patologik merupakan sesuatu yang sangat mengganggu bagi penderita yang mengalaminya, sehingga hal demikian perlu mendapat perhatian. Ansietas (kecemasan) adalah rasa ketakutan yang tidak menyenangkan dan samar-samar terhadap sesuatu yang tidak jelas (belum pernah terjadi). Selama individu masih dapat mengatasi stresor yang ada, maka ansietas tersebut masih bersifat normal. Jika individu tidak mampu mengatasi stresornya, maka akan timbul ansietas patologik yang merupakan respons terhadap ancaman yang 
sumbernya tidak diketahui, bersifat internal, samar-samar atau konfliktual ${ }^{15}$.

\section{Kecemasan memperingatkan} ancaman cedera pada tubuh, rasa takut, keputusasaan, kemungkinan hukuman, atau frustrasi dari kebutuhuan sosial tubuh, perpisahan dari orang yang dicintai, gangguan pada keberhasilan atau status seseorang, dan akhirnya ancaman pada kesatuan atau keutuhan seseorang. Kecemasan segera mengarahkan seseorang untuk mengambil langkah yang diperlukan untuk mencegahan caman atau meringankan akibatnya. Bencana alam merupakan salah satu faktor pemicu timbulnya kecemasan, karena manusia tidak bisa memprediksikan kapan bencana alam akan muncul. Bencana ialah peristiwa atau rangkaian peristiwa yang mengancam dan mengganggu kehidupan dan penghidupan masyarakat yang disebabkan, baik oleh faktor alam dan atau faktor non-alam maupun faktor manusia sehingga mengakibatkan timbulnya korban jiwa manusia, kerusakan lingkungan, kerugian harta benda, dan dampak psikologis ${ }^{16}$.

Hasil penelitian ini sesuai dengan penelitian yang dilakukan oleh ${ }^{16}$ didapatkan hasil bahwa responden yang tidakmengalamigangguankecemasanseba nyak 2 orang $(6,7 \%)$, responden yang mengalami gangguan kecemasan ringan sebanyak 10 orang (33,3\%), responden yang mengalami gangguan kecemasan sedang sebanyak 12 orang (40\%), dan responden yang mengalami gangguan kecemasan berat sebanyak 6 orang $(20,0 \%)$.

Berdasarkan hasil penelitian, teori, dan penelitian terkait peneliti berpendapat bahwa tingkat kecemasan pada responden terbanyak pada kategori cemas berat sebanyak 30 responden, hal itu terjadi karena bencana merupakan salah satu faktor pemicu timbulnya kecemasan, karena manusia tidak bisa memprediksikan kapan bencana akan muncul oleh karena itu responden pada korban bencana gempa, tsunami dan likuifaksi khawatir dan cemas akan kejadian gempa, tsunami dan likuifaksi terulang kembali atau terjadi gempa susulan.

\section{Tingkat Depresi}

Berdasarkan hasil analisis univariat pada penelitian ini, dari total 33 responden sebanyak 22 responden $(66,7 \%)$ mengalami depresi ringan dan 11 responden $(33,3 \%)$ mengalami depresi sedang.

Depresi merupakan gangguan mental umum yang ditandai dengan keadaan sedih terus-menerus, hilangnya keinginan melakukan aktivitas yang biasanya dinikmati dan ketidakmampuan untuk melakukan aktivitas sehari-hari setidaknya selama dua minggu. Depresimerupakaninteraksikomplekdarifak torsosial, psikologis dan biologis ${ }^{6}$. Depresi merupakan kondisi emosional yang ditandai dengan adanya perasaan yang sangat sedih, perasaan tidak berarti dan bersalah berupa kehilangan minat, semangat dalam melakukan aktivitas sehari-hari. Gangguan depresi terbagi menjadi dua yaitu: Major Depressive Disorder (MDD) dan Dysthymic Disorder (Gangguan Distimik/Distimia). Ciri dan gejala depresi diantaranya adalah: gangguan pola tidur, menurunnya tingkat aktivitas, sulit makan, diare dan energi lemah?.

Depresi di sebabkan oleh beberapa faktor salah satu diantaranya adalah faktor sosial yaitu berupa pasca bencana $^{8}$. Setelah peristiwa bencana, sebagian besar populasi korban bencana akan mengalami gangguan psikosis, diantaranya adalah depresi ${ }^{6}$. Menurut ${ }^{8}$ Bencana alam adalahbencana yang diakibatkan oleh peristiwa atau serangkaian peristiwa yang disebabkan 
oleh alam seperti gempa bumi, tsunami, gunung meletus, banjir, kekeringan, angin topan, dan tanah longsor. Bencana telah memberikan dampak yang begitu besar baik secara fisik, psikologis maupun sosial ${ }^{17}$. Dampak emosional jangka pendek yang masih terlihat jelas meliputi rasa takut dan cemasyang akut, rasa sedih dan rasa bersalah yang kronis, serta munculnya perasaan hampa. Pada sebagian orang perasaan-perasaan ini akan pulih seiring berjalannya waktu. Namun pada sebagian yang lain dampak emosional bencana dapat berlangsung lebih lama dan menjadi buruk ${ }^{8}$.

$\mathrm{Hal}$ ini sejalan dengan penelitian oleh ${ }^{9}$ yang menunjukan bahwa terdapat 32 orang $(96,96 \%)$ mengalami depresi dengan proporsi depresi ringan yaitu sebanyak 19 orang $(57,6 \%)$, depresi sedang 13 orang $(39,4 \%)$ dan yang tidak depresi 1 orang (3\%) yang diakibatkan tanah longsor. Selain itu berdasarkan penelitian $^{16}$ menunjukan bahwa ada hubungan antara gempa bumi dengan kejadian depresi.

Berdasarkan penjelasan teori dan penelitian terkait, peneliti berasumsi bahwa responden lebih banyak mengalami depresi ringan dikarenakan adanya faktor sosial yaitu: jenis kelamin/gender responden. Sebagian besar jenis kelamin responden pada penelitian ini adalah laki-laki sebanyak 20 responden (60,8\%). Pada umumnya, perempuan cenderung dua kali lebih banyak mengalami depresi dari pada pria akan tetapi pada penelitian ini responden terbanyak adalah laki-laki sehingga sebagian besar depresi yang dialami adalah depresi ringan yaitu $(66,7 \%)$.

\section{KESIMPULAN DAN SARAN}

Berdasarkan hasil penelitian yang telah dilakukandapat disimpulkan bahwa Tingkat stress terbanyak pada kategori berat $(51,5 \%)$, Tingkat kecemasan terbanyak pada kategori berat $(90,9 \%)$ dan tingkat depresi terbanyak pada kategori ringan $(66,7 \%)$.

Perlu dipertimbangkan untuk peneliti selanjutnya untukdapat memberikan intervensi terutama terapiterapi komplementer yang dapat menstimuli hormone endorphin dan sejenisnya sebagai anti cemas dan stress pada korban bencana dengan kegawatdaruratan psikologis untuk mencegah munculnya kondisi PTSD (Post Traumatic Stress Disorder).

\section{DAFTAR PUSTAKA}

1. Muhammad., Fadel., Ahmaddul. H., \& Dedy, I. (2018). PengembanganSistemMitigasiBenc anaAlamProvinsi Sumatera Barat Berbasis Android. JurnalTeknologilnformasi\&

Pendidikan, Vol. 11, No. 1, 29.

2. Astuti, R. L, dkk. (2010). EfektifitasTerapi Spiritual Emotional Freedom Technique (SEFT) untukMenurunkan Tingkat Stress PascaBencana pada WargaPascaErupsi Merapi Tahun 2010. ISSN 2407-9189,397

3. Pasau., Guntur, F., Gerald, H., Tamuntuan. (2017). PengamatanSaismitasGempaBumi Di Wilayah Pulau Sulawesi MenggunakanPerubahan Nilai a-b. Jurnal MIPA Unsrat Online ,Vol. 6, No. 1, 31,32.

4. Dwiyanti, M., dkk. (2018). GambaranRisikoGangguan Jiwa pada Korban BencanaAlamGempa di Lombok Nusa Tenggara Barat. Journal of Holistic Nursing and Health Sience, Vol. 1, No. 2.

5. Anggunsari, yulmia., \& Sri Hendarsih(2015).

Hubunganreligiusitasdengantingkatk ecemasandalammenghadapiBencan 
agempabumi di dusun Panjang panjangrejoPundong Bantul

6. WHO. (2017). Health Topics. Diakse s https://www.who.int/mental_health/ management/depression/en/

7. Aditomo, A., \&Retnowati, S. (2014). PerfeksionismeHargaDiri Dan KecenderunganDepresi Pada RemajaAkhir. JurnalPsikologi No.1 ISSN : 0215 - $8884,2$.

8. Badan Koordinasi Nasional PenangananBencana. 2007. PengenalanKarakteristikBencana dan UpayaMitigasinya Di Indonesia. (2th ed). Jakarta: DirektoratMitigasi.

9. Barri, A. (2009). Muhammadiyah dan KesiapsiagaanBencana. BandungRisalah MDMC.

10. Dirgayunita. A. (2016). Depresi: Ciri, Penyebab dan Penangannya. Jurnal An-nafs. Vol.1 No. 1 di akses di https://www.ejournal.iaitribakti.ac.id/i ndex.php/psikologi/article/view/235

11. Endike, Septia., YaslindaYaunin., Rima Semiarty.(2016). HubunganRisiko Tsunami terhadap Tingkat Ansietas pada Anak-anak di SDN 02 UlakKarang Tengah (Zona Merah) dan SDN 33 Kalumbuk (Zona Hijau). JurnalKesehatanAndalas. 2016; 5(2)

12. Baron, \&Bryne. (2005). PsikologiSosialJilid 2 (Penerjemah: Djuwita, R, dkk). Jakarta: Erlangga
13. Endiyono, \&Hidayah, N. I. (2018). Gambaran Post Traumatic Stress Disorder Korban Bencana Tanah Longsor di dusunjemblungkabupatenbanjarneg ara. Jawa Tengah: FakultasllmuKesehatanUniversitas Muhammadiyah Purwokerto.

14. Hawari. (2016). PendekatanPsikoreligi pada trauma bencana. Jakarta: FakultasKedokteranUniversitas Indonesia.

15. Taylor, E. S. (2013). Health Psychology Fifth Edition. USA: Mcgraw Hill, Inc.

16. Helton. W.S., dkk. (2013). Postdisaster depression and vigilance: a functional near-infrared spectroscopy study. Volume 226, Issue 3, pp 357-362. Diakses di https://link.springer.com/article/10.10 07\% 2Fs00221-013-3441-4

17. Setiawan. A, \&Pratitis. N.T. (2015). Religiusitas, DukunganSosial dan Resiliensi Korban Lumpur Lapindo Sidoarjo. JurnalPsikologi Indonesia. Vol.4, No. 02, hal 137-144. Diakses di https://www.researchgate.net/publ ication/330418883_Religiusitas_Duk ungan_Sosial_dan_Resiliensi_Korb an_Lumpur_Lapindo_Sidoarjo. 